\title{
Seasonal features of ultrafine particle volatility in the coastal Antarctic troposphere
}

\author{
K. Hara ${ }^{1, *}$, K. Osada ${ }^{3}$, C. Nishita-Hara ${ }^{3, * *}$, M. Yabuki ${ }^{1, * * *}$, M. Hayashi ${ }^{2}$, T. Yamanouchi ${ }^{1}$, M. Wada ${ }^{1}$, and \\ M. Shiobara ${ }^{1}$ \\ ${ }^{1}$ National Institute of Polar Research, Tokyo, Japan \\ ${ }^{2}$ Department of Earth System Science, Faculty of Science, Fukuoka University, Fukuoka, Japan \\ ${ }^{3}$ Graduate School of Environmental Studies, Nagoya University, Nagoya, Japan \\ *now at: Department of Earth System Science, Faculty of Science, Fukuoka University, Fukuoka, Japan \\ ** now at: Advances Materials Institute, Fukuoka University, Fukuoka, Japan \\ *** now at: Research Institute for Sustainable Humanosphere, Kyoto University, Kyoto, Japan
}

Received: 4 March 2011 - Published in Atmos. Chem. Phys. Discuss.: 13 May 2011

Revised: 2 August 2011 - Accepted: 8 September 2011 - Published: 21 September 2011

\begin{abstract}
The size distribution and volatility of ultrafine aerosol particles were measured using scanning mobility particle sizer and thermodenuder at Syowa Station during the 46-47 Japanese Antarctic Research Expeditions (20052007). The relative abundance of non-volatile particles in a $240{ }^{\circ} \mathrm{C}$ scan was approximately $20 \%$ during the summer, whereas the abundance of non-volatile particles increased by $>90 \%$ during the winter-spring. Most ultrafine particles were volatilized at temperature of $150-210^{\circ} \mathrm{C}$. This volatility was consistent well to major aerosol constituents $\left(\mathrm{NH}_{4}^{+}, \mathrm{SO}_{4}^{2-}\right.$ and $\left.\mathrm{CH}_{3} \mathrm{SO}_{3}^{-}\right)$during the summer. In contrast, major constituents of ultrafine particles were sea-salts $\left(\mathrm{Na}^{+}\right.$and $\left.\mathrm{Cl}^{-}\right)$in winter-spring. Therefore, the seasonal feature of volatility of ultrafine particles at Syowa was associated with seasonal variations of the major aerosol constituents. Although the relative abundance of non-volatile particles was usually higher during the winter-spring, the abundance dropped occasionally to $<30 \%$. The lower abundance of non-volatile ultrafine particles during winter-spring corresponded to the lower number concentration of ultrafine particles and transport from the free troposphere over Antarctica.
\end{abstract}

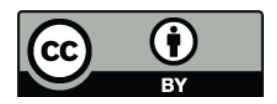

Correspondence to: K. Hara (harakei@fukuoka-u.ac.jp)

\section{Introduction}

In terms of the number concentration, aerosol particles in polar regions are dominated mostly in ultrafine mode: smaller than $100 \mathrm{~nm}$ in diameter. Using a condensation nuclei $(\mathrm{CN})$ counter, continuous measurements of ultrafine particles have been made at the Antarctic regions, for example, at Syowa Station (Ito, 1989, 1993; Hayashi et al., 2010), Neumayer Station (Jaenicke et al., 1992; Weller et al., 2002), Mawson Station (Gras, 1993) and Amundsen-Scott Station (Bodhaine, 1995). Seasonal variations of $\mathrm{CN}$ in the Antarctic region show a maximum in summer and minimum in winter (e.g. Ito, 1993; Bodhaine, 1995; Hayashi et al., 2010).

Most ultrafine particles in Antarctica during the austral summer are regarded as supplied by new particle formation from aerosol precursors such as $\mathrm{H}_{2} \mathrm{SO}_{4}$ gas (e.g. Ito, 1993). Previous investigations have suggested that aerosol precursors are $\mathrm{H}_{2} \mathrm{SO}_{4}$ oxidized from dimethylsulfide (DMS) derived from oceanic bioactivity (e.g. Gras, 1993; Ito, 1993; Meskhidze and Nenes, 2006). Moreover, recent works suggested that organics derived from oceanic bioactivity played an important role in new particle formation and particle growth in the Antarctic regions (e.g. Meskhidze and Nenes, 2006; Asmi et al., 2010). Because ultrafine particles can act as cloud condensation nuclei $(\mathrm{CCN})$, the likelihood exists that aerosols indirectly affect climate change, as suggested by Shaw $(1983,1988)$ and Charlson et al. (1987). Consequently, interaction among aerosols, oceanic bioactivity, cloud processes, and climate change has been of increasing interest, even that in the Antarctic regions. In contrast to

Published by Copernicus Publications on behalf of the European Geosciences Union. 
indirect effects, direct effects can be negligible in the Antarctic regions (Bodhaine, 1995) because of the lower number density of aerosol particles. For the better understanding, aerosol measurements have often been conducted in Antarctic coastal areas during the summer (e.g. Meskhidze and Nenes, 2006). In addition to $\mathrm{CN}$ measurements, size distributions of ultrafine particles in the summer were measured at Aboa Station (Koponen et al., 2003; Asmi et al., 2010) and at Amundsen-Scott Station (Park et al., 2004) to obtain knowledge about new particle formation, while a few yearround measurements of size distributions of ultrafine particles have also been conducted in other Antarctic regions (e.g. Ito, 1993; Osada et al., 2010). Although the seasonal variation of $\mathrm{CN}$ concentration showed a minimum in the winter, the $\mathrm{CN}$ concentration increased occasionally to several hundred cubic centimeters, even in winter. Ito (1993) pointed out that the increased $\mathrm{CN}$ concentration in the winter corresponds to transport of oceanic air masses to Syowa Station. Sources of CN (or ultrafine particles), however, were not discussed well.

Aerosol volatility has often been measured using pyrolytic methods to obtain indirect information about aerosol constituents (e.g. Ito and Iwai, 1981; O'Dowd and Smith, 1993; O'Dowd et al., 1997). In general, secondary particles, formed by "gas-to-particle conversion", have higher volatility; primary particles such as sea-salt and mineral particles have less volatility. Aerosol volatility measurements were performed in the Antarctic regions, for instance, Syowa (Ito and Iwai, 1981), Southern Ocean (O'Dowd et al., 1997) and Aboa (Asmi et al., 2010). Ito and Iwai (1981) showed that non-volatile particles were dominated in some cases of higher aerosol concentrations under the storm conditions in winter. O'Dowd et al. (1997) indicated high aerosol volatility over the Southern Ocean in the summer. Asmi et al. (2010) presented high volatility of aerosol particles with size of particle diameter $\left(D_{\mathrm{p}}\right)=25,50$, and $90 \mathrm{~nm}$ during summer. Relative abundance of non-volatile particles, however, and seasonal features of aerosol volatility were not obtained in these studies, since long-term measurement of aerosol volatility has not been made in the Antarctic regions. In this study, in addition to continuous measurements of aerosol size distribution, aerosol volatility measurements were made to elucidate the seasonal variation and volatility of ultrafine particles at Syowa Station (Antarctic coast).

\section{Measurements and analysis}

Aerosol measurements were conducted as a part of an aerosol measurement program during the 45-47th Japanese Antarctic research expedition (JARE: 2004-2007) at Syowa Station, Antarctica $\left(39^{\circ} \mathrm{E}, 69^{\circ} \mathrm{S}\right)$. Syowa station is located on East Ongul Island in Lützow Holm bay. Sea-ice margin was distant, from Syowa, approximately $100 \mathrm{~km}$ during the summer and $1000 \mathrm{~km}$ during the winter-spring. Although the drought soil surface appeared around the observatory approximately in January-mid February, the surface was covered with snow in mid February-December. Seasonal features of sea-ice extent off Syowa shows a minimum around February and a maximum in September-October (e.g. Kusunoki, 1979). All aerosol instruments were installed into a "clean air observatory". The observatory was built at the windward side ca. $400 \mathrm{~m}$ distant from the main area of Syowa Station where a diesel power generator is located. Sample air was taken from air inlet fixed on the sampling tower. Air inlet was set approximately $5 \mathrm{~m}$ above the ground. Based on simultaneous aerosol measurements inside and outside the observatory using handheld optical particle counter (KR12, RION) and condensation particle counter (CPC-3007, TSI Inc.), aerosol passing efficiency in inlet and tubing was examined as follows; $91 \%$ in $D_{\mathrm{p}}>0.3 \mu \mathrm{m}, 93 \%$ in $D_{\mathrm{p}}>0.5 \mu \mathrm{m}, 88 \%$ in $D_{\mathrm{p}}>1.0 \mu \mathrm{m}$, and $87 \%$ in $D_{\mathrm{p}}>2.0 \mu \mathrm{m}$. As far as several simultaneous measurements, very little difference was obtained in $\mathrm{CN}$ concentration. Although aerosol particles with size of $D_{\mathrm{p}}>5.0 \mu \mathrm{m}$ were significantly lost in inlet and tube, the passing efficiency was uncertain because of the lower number density of $D_{\mathrm{p}}>5.0 \mu \mathrm{m}$ in the ambient atmosphere and no counts of $D_{\mathrm{p}}>5.0$ by OPC inside the observatory during the simultaneous measurements. Details of the observatory (e.g. design of inlet and tubing) were described by Osada et al. (2006) and Hara et al. (2008).

The CN concentration $\left(D_{\mathrm{p}}>10 \mathrm{~nm}\right)$ was monitored at 1min intervals using a condensation particle counter (CPC: 3010; TSI Inc.). A scanning mobility particle sizer (SMPS: 3936-N-25; TSI Inc.) was used to measure the size distribution of ultrafine particles $\left(D_{\mathrm{p}}: 5-168 \mathrm{~nm}\right)$. The SMPS measurements were conducted during February 2004-December 2006. The SMPS (3934; TSI Inc.) with a thermodenuder (TSMPS) was operated to obtain aerosol volatility measurements $\left(D_{\mathrm{p}}: 10-395 \mathrm{~nm}\right)$. The thermodenuder was installed before a differential mobility analyzer (3071; TSI Inc.) in TSMPS. CPCs for SMPS and TSMPS were 3025A (TSI Inc.) and 3022A (TSI Inc.), respectively. The TSMPS was operated from mid-February 2005 to July 2006; its operation was halted in July 2006 because of mechanical trouble. The aerosol volatility was measured at room temperature (ca. $20^{\circ} \mathrm{C}$ ), $100^{\circ} \mathrm{C}$, and $240^{\circ} \mathrm{C}$, with temperatures controlled using a programmable controller (E5AK; Omron Corp.) and a heater. Considering flow rate and inner diameter of tubing, residence time of aerosol particles in the thermodenuder was approximately $1 \mathrm{~s}$. Aerosol volatility was assessed for one hour at each temperature because of the low number concentration in Antarctic regions (as presented in Fig. 1). Therefore, $280 \mathrm{~min}$ (including time for heating and cooling) were necessary to complete one cycle of TSMPS measurements. The scanning time for one scan was set to $5 \mathrm{~min}$ in both SMPS and TSMPS measurements.

Local contamination can occur at the observatory when (1) the wind speed is lower, (2) wind comes from direction of the main area, and (3) snow vehicles pass through the 


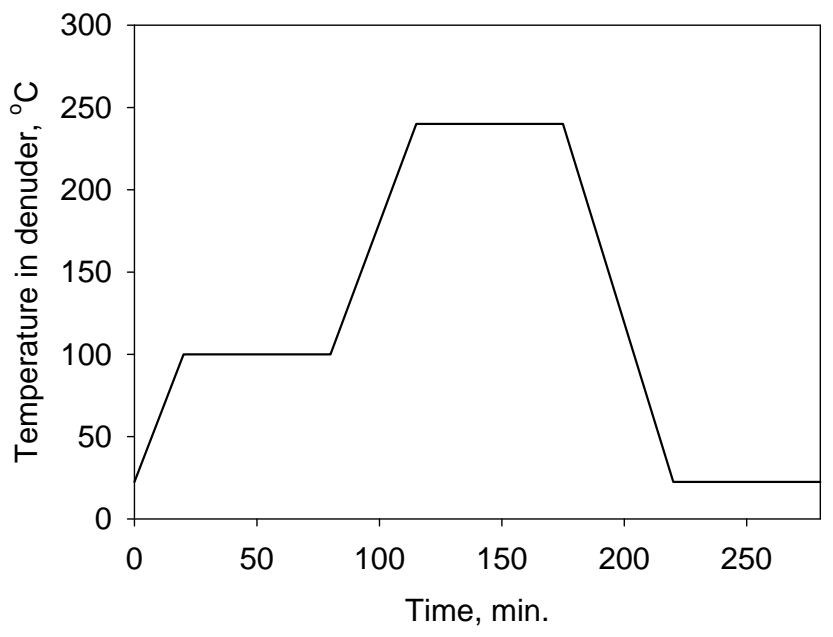

Fig. 1. Variation of temperature of the thermodenuder in TSMPS measurements.

windward side of the observatory. The $\mathrm{CN}$ concentration is also extremely sensitive to local contamination. Therefore, wind data and $\mathrm{CN}$ data were used to detect local contamination. All aerosol data with contaminable wind direction of $180-300^{\circ}$ were excluded from analyses. In addition, aerosol data were filtered when the standard deviation of 10-minmean $\mathrm{CN}$ concentration was greater than $10 \%$ and when the wind speed was $<15 \mathrm{~m} \mathrm{~s}^{-1}$. Using those criteria, local contamination was distinguished from moving contamination (e.g. snow vehicles). When the wind speed became greater than $15 \mathrm{~m} \mathrm{~s}^{-1}$, it came from the direction of the prevailing wind (clean air sector) at Syowa Station. Snow vehicles were not operated on the windward side (sea-ice area) under conditions of strong winds and low visibility because of JARE safety guidelines, so local contamination by combustion processes cannot occur in strong winds of $>15 \mathrm{~m} \mathrm{~s}^{-1}$. For these reasons, we retained the aerosol data as "non-contaminated data" in the case of wind speeds of $>15 \mathrm{~m} \mathrm{~s}^{-1}$.

Aerosol samples were collected for chemical analyses using a two-stage mid-volume impactor with a back-up filter (cut-off diameter, 0.2 and $2.0 \mu \mathrm{m}$ ). To avoid local contamination, air sucking was controlled using a wind selector. Samples were taken for 2-3 days depending on meteorological conditions. Procedures for sample analysis using ion chromatography were in accordance with those described by Hara et al. (2004).

\section{Results and discussion}

\subsection{Estimation of aerosol volatility}

In order to discuss aerosol volatility, abundance of nonvolatile particles was estimated using aerosol data obtained from TSMPS and SMPS in the following sections. Figure 2 depicts relationship in room temperature scan among

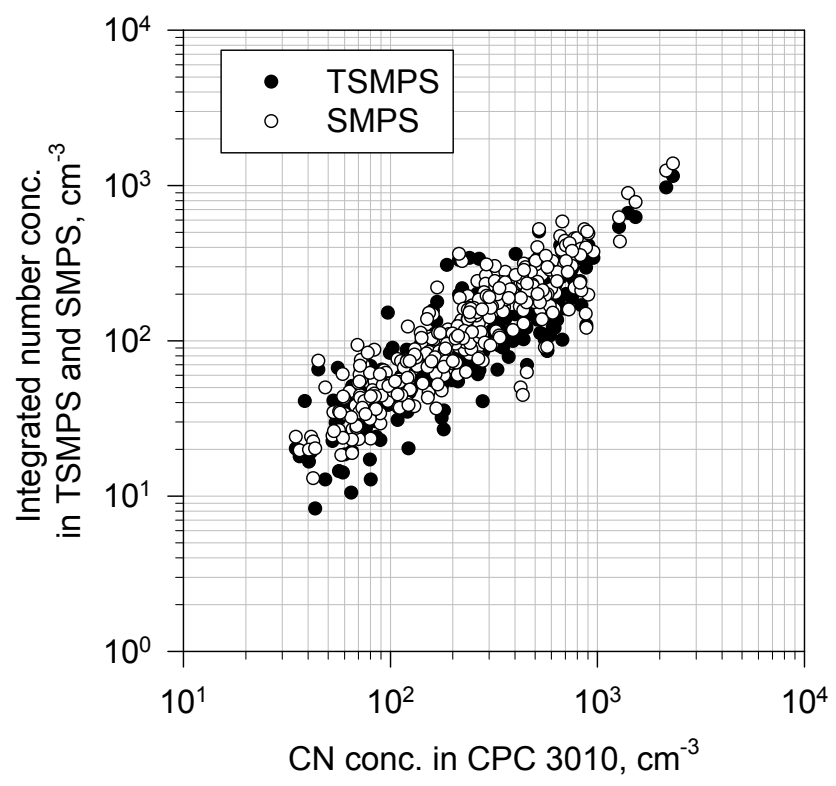

Fig. 2. Relationship among CN concentration in CPC-3010, the integrated number concentrations ( $D_{\mathrm{p}}: 10-167 \mathrm{~nm}$ ) of TSMPS and SMPS during the room temperature scan.

$\mathrm{CN}$ concentration measured by CPC-3010 without the upper cut-off by impactor and the integrated number concentrations $\left(D_{\mathrm{p}}>10-168 \mathrm{~nm}\right)$ measured by TSMPS and SMPS with upper cut-off by impactor. The integrated number concentrations $\left(D_{\mathrm{p}}>10-168 \mathrm{~nm}\right)$ in TSMPS and SMPS were correlated well with $\mathrm{CN}$ concentration (CPC-3010), although the upper cut-off by the impactor leads to underestimation of the number concentrations in TSMPS and SMPS. The relationship was estimated as follows;

$$
\left[\mathrm{CN}_{\mathrm{TSMPS}}\right]=0.423 \cdot\left[\mathrm{CN}_{\mathrm{CPC}-3010}\right]+1.401\left(R^{2}=0.868\right),
$$

and

$$
\left[\mathrm{CN}_{\mathrm{SMPS}}\right]=0.482 \cdot\left[\mathrm{CN}_{\mathrm{CPC}-3010}\right]+8.680\left(R^{2}=0.804\right) \text {. }
$$

Here, $\mathrm{CN}_{\mathrm{TSMPS}}, \mathrm{CN}_{\mathrm{SMPS}}$, and $\mathrm{CN}_{\mathrm{CPC}-3010}$ mean the integrated number concentrations in TSMPS, SMPS, and CPC, respectively. Although $\mathrm{CN}_{\text {TSMPS }}$ was slightly lower than $\mathrm{CN}_{\text {SMPS }}$, this difference may be caused by long tubing of themordenuder. Relation between $\mathrm{CN}_{\mathrm{TSMPS}}$ and $\mathrm{CN}_{\mathrm{SMPS}}$ is estimated as follows,

$$
\left[\mathrm{CN}_{\mathrm{SMPS}}\right]=1.186 \cdot\left[\mathrm{CN}_{\mathrm{TSMPS}}\right]+13.511\left(R^{2}=0.969\right) \text {. }
$$

Because of high correlation, consequently, abundance of non-volatile particles can be estimated using TSMPS and SMPS data. Considering that $\mathrm{CN}$ concentration was varied largely depending on meteorological conditions at Syowa (e.g. Hara et al., 2010, 2011b) and that SMPS data was taken simultaneously with TSMPS data, TSMPS and SMPS data was used to obtain the number fraction of non-volatile particles in this study. First, the number concentrations 


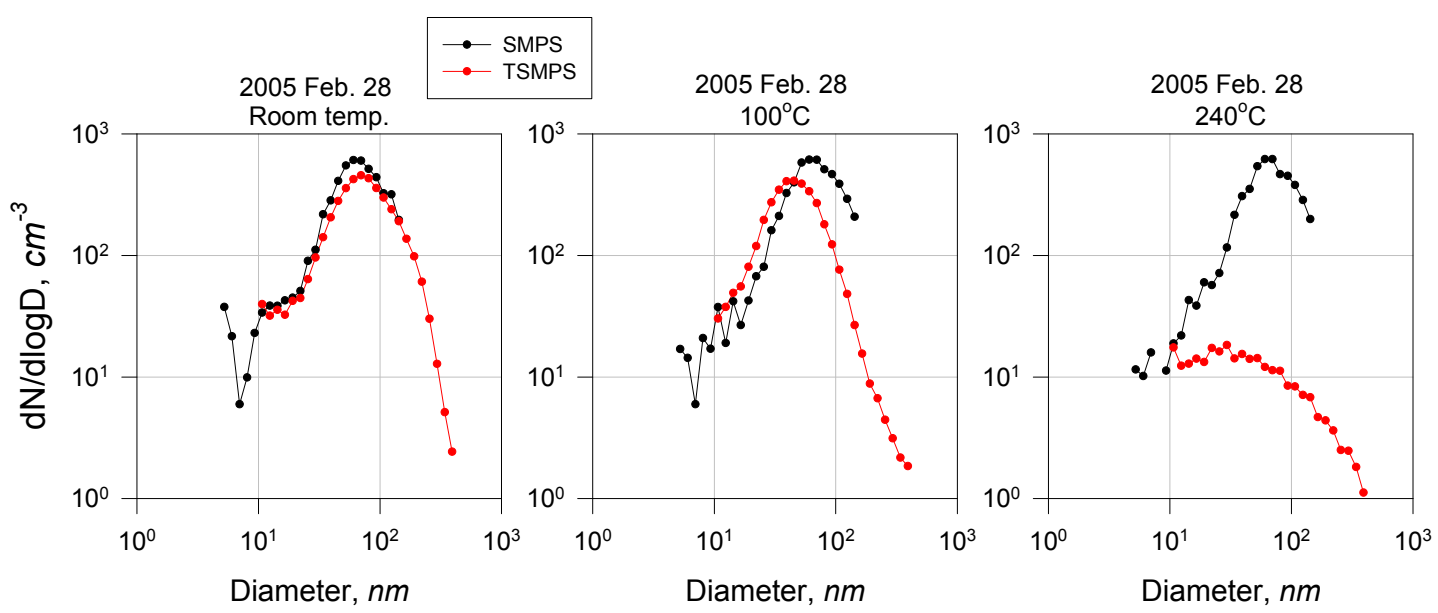

Fig. 3. Typical examples of aerosol size distribution measured on 28 February 2005 at Syowa Station, Antarctica under the conditions of room temperature (ca. $20^{\circ} \mathrm{C}$ ), $100^{\circ} \mathrm{C}$ and $240^{\circ} \mathrm{C}$.

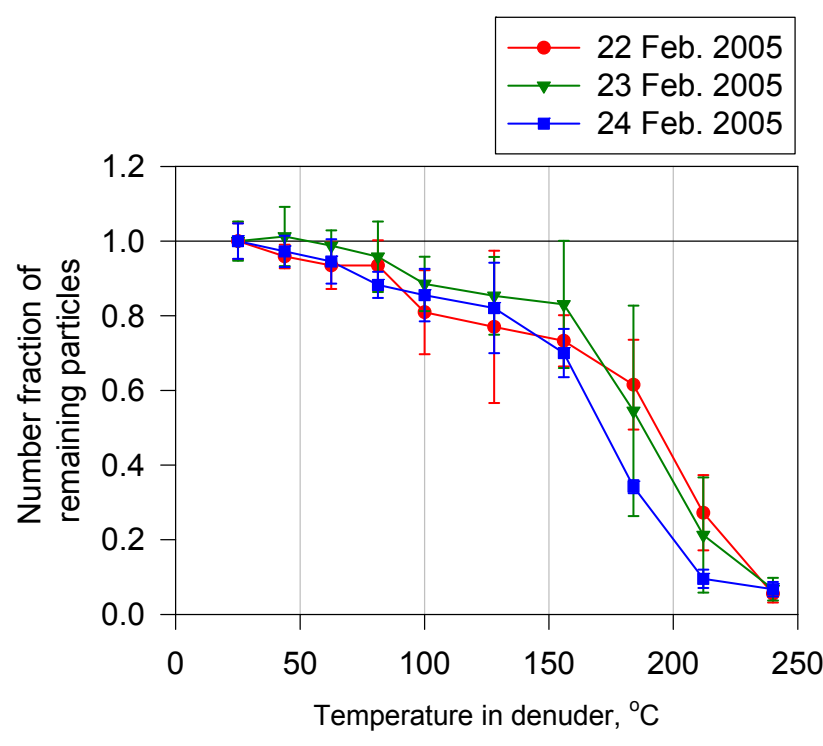

Fig. 4. Typical examples of the relation between temperature and volatility of aerosol particles at Syowa Station on 22-24 February 2005. Error bars show the standard deviation.

of TSMPS and SMPS during the $240{ }^{\circ} \mathrm{C}$ scan were integrated in size range of $D_{\mathrm{p}}=10-168 \mathrm{~nm}$ to obtain total number concentrations ( $\mathrm{CN}_{\text {TSMPS-240 }}$ and $\mathrm{CN}_{\text {SMPS-240 }}$ ). Second, the integrated TSMPS data in the $240^{\circ} \mathrm{C}$ scan ( $\left.\mathrm{CN}_{\mathrm{TSMPS}}-240\right)$ was corrected using the relationship between $\mathrm{CN}_{\text {TSMPS }}$ and $\mathrm{CN}_{\text {SMPS }}$, because of the underestimation in TSMPS data. Then the number fraction of non-volatile particles $\left(\mathrm{CN}_{\mathrm{TSMPS}-240} / \mathrm{CN}_{\mathrm{SMPS}-240}\right)$ in $D_{\mathrm{p}}=10-168 \mathrm{~nm}$ was calculated in this study. The number fraction calculated from only TSMPS data was correlated well to the fraction from TSMPS and SMPS data expect the data in the period with drastic change of $\mathrm{CN}$ concentration.

\subsection{Size distribution and volatility of ultrafine particles}

\subsubsection{Size distribution and volatility during summer}

Figure 3 depicts examples of size distributions of ultrafine particles obtained during the summer. The size distribution of TSMPS at room temperature was matched well to that of SMPS. In the $100^{\circ} \mathrm{C}$ scan, the Aitken mode $\left(D_{\mathrm{p}}: 20-\right.$ $100 \mathrm{~nm}$ ) in TSMPS was shifted to a smaller size relative to that in SMPS. The number concentrations in fine mode $\left(D_{\mathrm{p}}>100 \mathrm{~nm}\right)$ in TSMPS decreased markedly. Considering the different temperatures of ambient air and sampled air in the observatory, the size distribution was measured under the dry conditions (relative humidity, usually $<10 \%$ ). Therefore, the change of the size distribution in $100^{\circ} \mathrm{C}$ cannot be explained by aerosol hygroscopicity. Consequently, the feature of size distribution might be associated with volatilization of semi-volatile species such as sulfates and organics. Asmi et al. (2010) reported that ultrafine particles were composed of volatile species in addition to sulfuric acid. Most of the aerosol particles were volatized in TMSPS with $240^{\circ} \mathrm{C}$ scan. For this study, we define the remaining particles in $240^{\circ} \mathrm{C}$ scan as "non-volatile particles".

Figure 4 presents an example of the relation between scan temperature and the ratio of $\mathrm{CN}$ (total number) concentration ( $D_{\mathrm{p}}: 10-168 \mathrm{~nm}$ ) estimated from TSMPS and SMPS measurements. The ratio decreased gradually and slightly from room temperature to $150^{\circ} \mathrm{C}$, although the ratio dropped considerably in $150-210^{\circ} \mathrm{C}$. Finally, the ratio at $240^{\circ} \mathrm{C}$ was consistently lower than 0.2 . Results show that the $240^{\circ} \mathrm{C}$ scan can discriminate volatile particles from non-volatile particles in Antarctic regions. Similar volatility was observed at Syowa Station (Ito and Iwai, 1981), at the Antarctic Ocean (O'Dowd et al., 1997), and at the marine boundary layer at mid-latitudes (O'Dowd and Smith, 1993). 


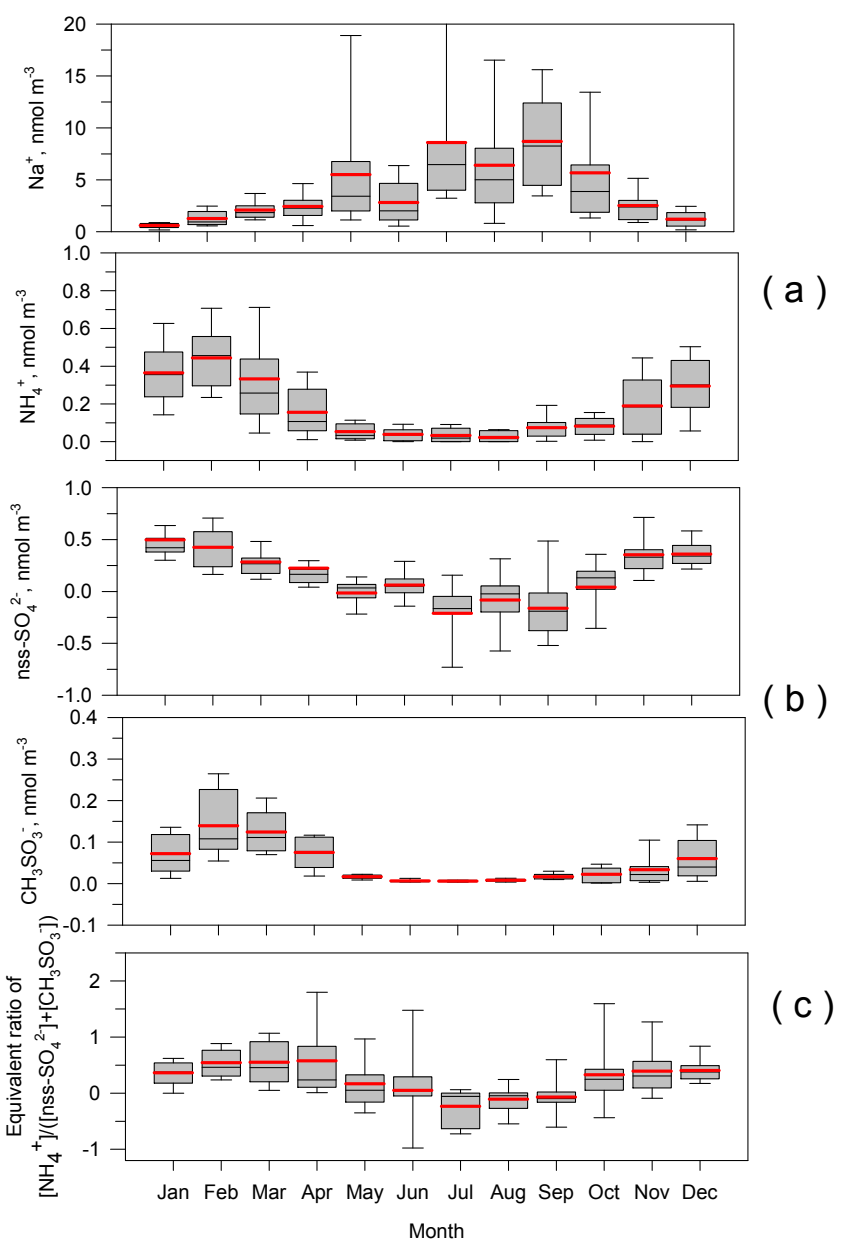

Fig. 5. Seasonal variation of the concentrations of $\mathrm{NH}_{4}^{+}$, nss$\mathrm{SO}_{4}^{2-}$, and $\mathrm{CH}_{3} \mathrm{SO}_{3}^{-}$, and the equivalent ratio of $\mathrm{NH}_{4}^{+} /($nss$\mathrm{SO}_{4}^{2-}+\mathrm{CH}_{3} \mathrm{SO}_{3}^{-}$) in aerosol particles with size of $D_{\mathrm{p}}<0.2 \mu \mathrm{m}$ at Syowa Station. Concentration of $\mathrm{nss}^{-\mathrm{SO}_{4}^{2-}}$ was estimated using $\mathrm{Na}^{+}$concentration and the bulk seawater ratio (Wilson, 1975). In box plots, the upper bar, upper box line, black middle box line, bottom box line, and bottom bar respectively denote values of $90 \%$, $75 \%, 50 \%$ (median), $25 \%$ and $10 \%$. The red line represents mean values.

In Antarctic regions during the summer, major aerosol constituents are sulfates and methanesulfonates, as suggested by results of previous studies (e.g. Ito, 1993; Minikin et al., 1998). Figure 5 portrays seasonal variations of concentrations of non-sea-salt sulfate (nss- $\mathrm{SO}_{4}^{2-}$ ) and methanesulfonate $\left(\mathrm{CH}_{3} \mathrm{SO}_{3}^{-}\right)$in $D_{\mathrm{p}}<0.2 \mu \mathrm{m}$, and the equivalent ratio of $\mathrm{NH}_{4}^{+}$to sum of nss-SO $\mathrm{SO}_{4}^{2-}$ and $\mathrm{CH}_{3} \mathrm{SO}_{3}^{-}$at Syowa Station. Higher concentrations of nss- $\mathrm{SO}_{4}^{2-}$ and $\mathrm{CH}_{3} \mathrm{SO}_{3}^{-}$were obtained for $D_{\mathrm{p}}<0.2 \mu \mathrm{m}$ during the summer at Syowa Station. These ions were dominant in aerosol constituents of ultrafine particles (details are presented later). Median equivalent ratios of $\mathrm{NH}_{4}^{+}$to nss- $\mathrm{SO}_{4}^{2-}+\mathrm{CH}_{3} \mathrm{SO}_{3}^{-}$were close to
0.5 in $D_{\mathrm{p}}<0.2 \mu \mathrm{m}$ during the summer. The ratio occasionally reached ca. 1. Consequently, ultrafine particles might be composed dominantly of $\left(\mathrm{NH}_{4}\right)_{2} \mathrm{SO}_{4}, \mathrm{NH}_{4} \mathrm{HSO}_{4}$, and $\mathrm{CH}_{3} \mathrm{SO}_{3} \mathrm{NH}_{4}$ rather than $\mathrm{H}_{2} \mathrm{SO}_{4}$ and $\mathrm{CH}_{3} \mathrm{SO}_{3} \mathrm{H}$. According to O'Dowd and Smith (1993) and O'Dowd et al. (1997), $\mathrm{H}_{2} \mathrm{SO}_{4}$ and $\mathrm{CH}_{3} \mathrm{SO}_{3} \mathrm{H}$ can be volatilized at temperatures lower than $100^{\circ} \mathrm{C}$, although $\left(\mathrm{NH}_{4}\right)_{2} \mathrm{SO}_{4}$ and $\mathrm{NH}_{4} \mathrm{HSO}_{4}$ have large volatility in $180-220^{\circ} \mathrm{C}$. In our laboratory experiments using TMPS, $\left(\mathrm{NH}_{4}\right)_{2} \mathrm{SO}_{4}$ particles were volatilized in 170 $180^{\circ} \mathrm{C}$, similar to the result in Fig. 4 . Because of the equivalent ratio of $\mathrm{NH}_{4}^{+}$to nss- $\mathrm{SO}_{4}^{2-}+\mathrm{CH}_{3} \mathrm{SO}_{3}^{-}$(Fig. 5c) and volatility of $\left(\mathrm{NH}_{4}\right)_{2} \mathrm{SO}_{4}$ and $\mathrm{NH}_{4} \mathrm{HSO}_{4}$, the aerosol volatility in Fig. 4 might be mostly attributable to volatilization of $\left(\mathrm{NH}_{4}\right)_{2} \mathrm{SO}_{4}$ and $\mathrm{NH}_{4} \mathrm{HSO}_{4}$ in ultrafine mode.

\subsubsection{Size distribution and volatility in the winter}

Figure 6 depicts examples of size distributions in the winter. Similar to size distributions in summer, the size distribution of TSMPS was matched to SMPS at room temperature. Although the Aitken-mode was shifted to smaller size during the summer (as mentioned above), no marked difference of size distribution was observed in the $100{ }^{\circ} \mathrm{C}$ scan in the winter. Furthermore, most ultrafine particles remained even in the $240^{\circ} \mathrm{C}$ scan, which suggests that ultrafine particles mostly comprised non-volatile species during the winter.

\subsection{Seasonal variation of volatility and aerosol constituents}

Figure 7 depicts seasonal variations of the number fraction of non-volatile particles $\left(D_{\mathrm{p}}: 10-168 \mathrm{~nm}\right)$ and aerosol constituents of anion in $D_{\mathrm{p}}<0.2 \mu \mathrm{m}$. The number fraction of non-volatile particles dropped to less than $20 \%$ in the summer at Syowa Station. Predominance of volatile particles was observed from mid-October until early April in $2005 / 2006$. In contrast to the summer, the number fraction of non-volatile particles was often elevated to $>90 \%$ during the winter-spring. In spite of the dominance of non-volatile particles in the winter, the number fraction dropped occasionally to about $20 \%$, even in the winter. The low fraction of nonvolatile particles in the winter is discussed in Sect. 3.4.

Figure $7 \mathrm{~b}$ shows that major aerosol constituents were $\mathrm{SO}_{4}^{2-}, \mathrm{CH}_{3} \mathrm{SO}_{3}^{-}, \mathrm{Cl}^{-}$, and $\mathrm{NO}_{3}^{-}$at Syowa Station. During the summer, the molar fractions of $\mathrm{SO}_{4}^{2-}$ and $\mathrm{CH}_{3} \mathrm{SO}_{3}^{-}$ increased by $>50 \%$. Although $\mathrm{SO}_{4}^{2-}$ was obtained in the winter, $\mathrm{SO}_{4}^{2-}$ in the winter was equivalent mostly to sea-salt $\mathrm{SO}_{4}^{2-}$. As described above, major constituents of volatile particles in the summer were sulfates and methanesulfonates. Taking higher concentration of $\mathrm{CH}_{3} \mathrm{SO}_{3}^{-}$in the summer into account, the oceanic bioactivity might be potential sources for aerosol precursors (e.g. DMS) converted to volatile particles, as suggested by Minikin et al. (1998).

In contrast to aerosol constituents in the summer, the molar fraction of chloride $\left(\mathrm{Cl}^{-}\right)$reached $>90 \%$ in the winter. 

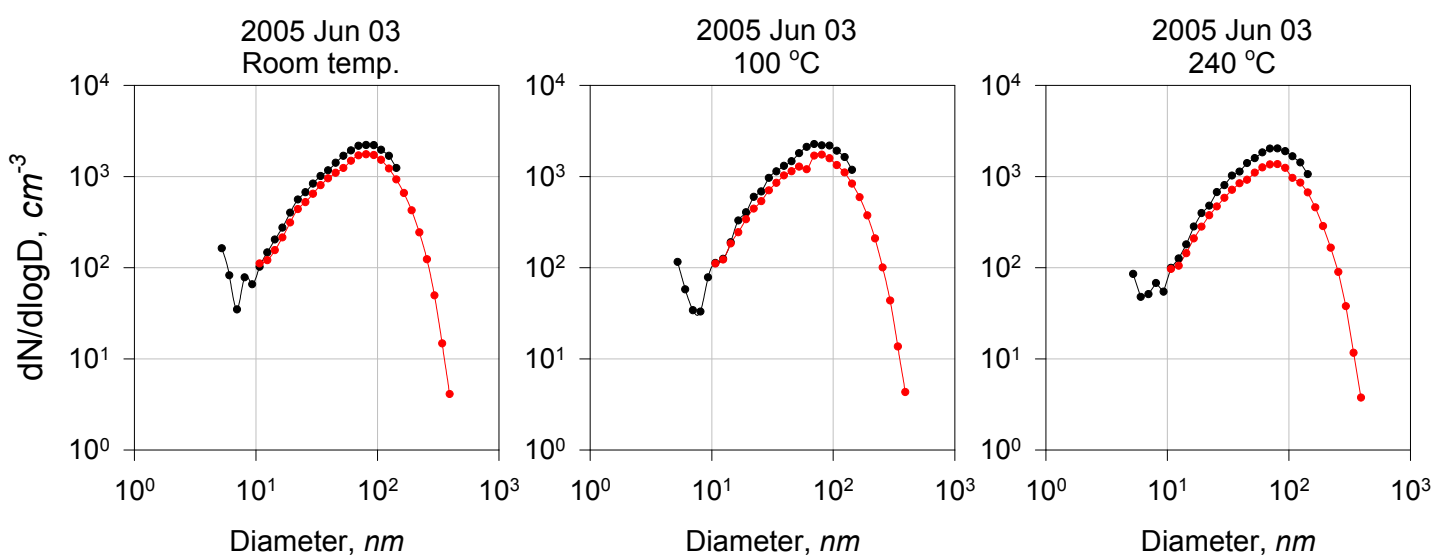

Fig. 6. Typical examples of aerosol size distribution measured on 3 June 2005 at Syowa Station, Antarctica at room temperature (ca. $20^{\circ} \mathrm{C}$ ), $100^{\circ} \mathrm{C}$ and $240^{\circ} \mathrm{C}$.

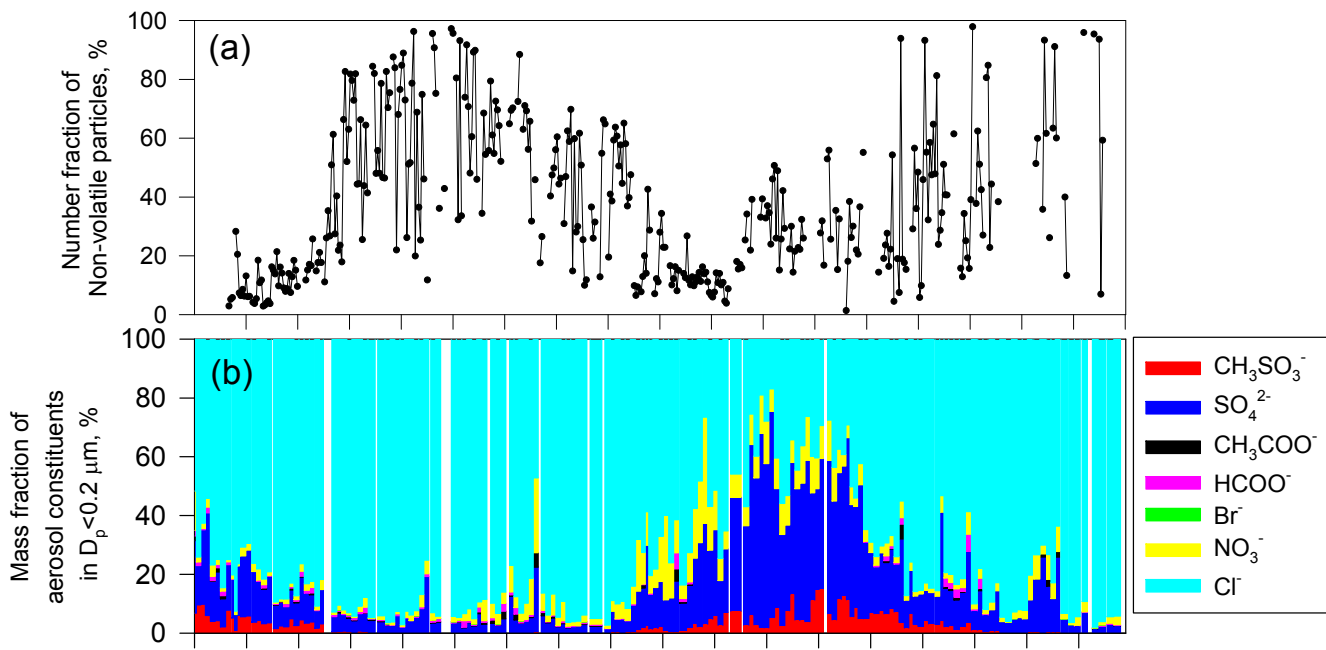

Feb Mar Apr May Jun Jul Aug Sep Oct Nov Dec Jan Feb Mar Apr May Jun Jul

$2005 / 2006$

Fig. 7. Seasonal variations of the number fraction of non-volatile particles and mass fraction of water-soluble aerosol constituents of anions in $D_{\mathrm{p}}<0.2 \mu \mathrm{m}$ at Syowa Station.

Plausible chemical states of particulate $\mathrm{Cl}^{-}$in the troposphere are mainly sea-salts (e.g. $\mathrm{NaCl}$ ) and $\mathrm{NH}_{4} \mathrm{Cl}$. Because of the thermal decomposition, however, $\mathrm{NH}_{4} \mathrm{Cl}$ can be classified into the volatile fraction in this study. Furthermore, the $\mathrm{Cl}^{-}$concentration was correlated well to $\mathrm{Na}^{+}$concentration in $D_{\mathrm{p}}<0.2 \mu \mathrm{m}$ :

$\left(\mathrm{Cl}^{-}\right)=1.3344\left(\mathrm{Na}^{+}\right)-0.4589\left(R^{2}=0.998\right)$.

Therefore, $\mathrm{Cl}^{-}$is identifiable as a sea-salt constituent. Seasalt particles are vaporized at temperatures higher than $700^{\circ} \mathrm{C}$ (O'Dowd and Smith, 1993). Therefore, sea-salt particles are classified as "non-volatile particles" in this study. When mineral particles and soot particles are present, these particles are identifiable as non-volatile particles using the criteria of the present study. The mass concentrations of mineral particles and soot, however, can be estimated to unrealistically high values along the Antarctic coast, assuming that minerals and soot are dominant as non-volatile particles. Consequently, most non-volatile particles in the winter might be sea-salts. Recent observations in the marine boundary layer (Clarke et al., 2006) and a model study (Mårtensson et al., 2003) reported that ultrafine sea-salt particles can be released from the ocean surface through bubble bursting. Therefore, the ocean surface might be a potential source for ultrafine sea-salt particles at Syowa during the winter.

In addition to emissions of sea-salt particles from ocean surface, previous studies (e.g. Wagenbach et al., 1998; Hara et al., 2004) have pointed out that sea-salt particles are released also from the sea-ice surface along the Antarctic coast during winter. As portrayed in Fig. 8, a negative slope 


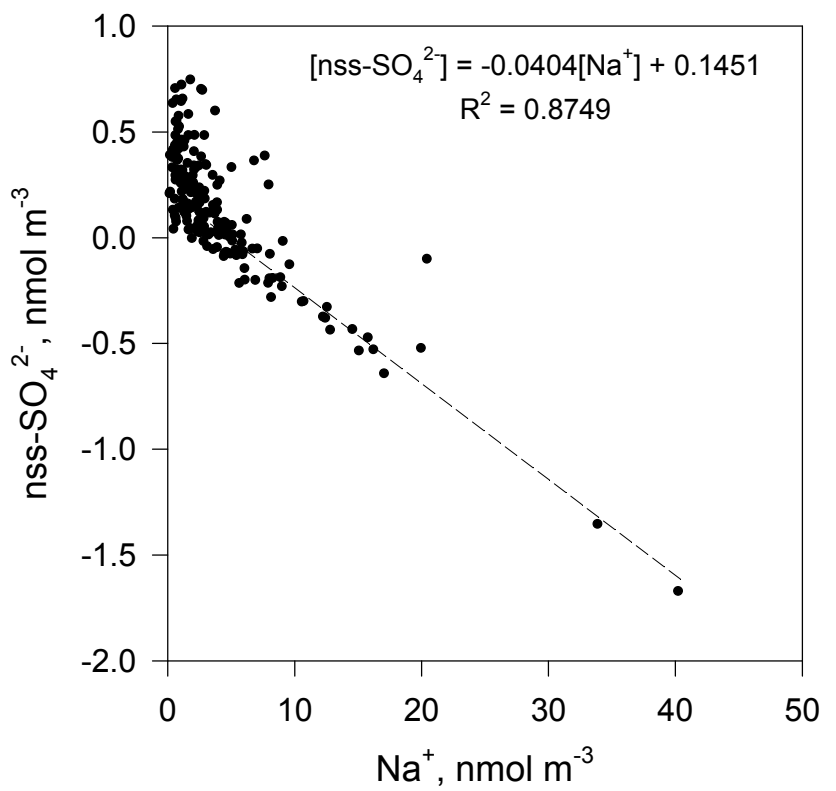

Fig. 8. Relation between $\mathrm{Na}^{+}$and nss- $\mathrm{SO}_{4}^{2-}$ in $D_{\mathrm{p}}<0.2 \mu \mathrm{m}$ at Syowa Station. The concentration of nss- $\mathrm{SO}_{4}^{2-}$ was calculated using $\mathrm{Na}^{+}$and bulk seawater ratio (Wilson, 1975).

between $\mathrm{Na}^{+}$concentration and nss- $\mathrm{SO}_{4}^{2-}$ was clearly observed, even for $D_{\mathrm{p}}<0.2 \mu \mathrm{m}$. A similar negative slope was observed by Wagenbach et al. (1998) and Hara et al. (2004), who inferred that the negative slope resulted from sulfate depletion (precipitation of mirabilite; $\mathrm{Na}_{2} \mathrm{SO}_{4} 10 \mathrm{H}_{2} \mathrm{O}$ ) on sea ice during sea ice formation. Therefore, the relation with the negative slope strongly suggests that sea-salt particles derived from the sea-ice interface were distributed, even in ultrafine mode. Although sea-salt particles are expected to be released to a considerable degree through wind erosion under the strong winds that prevail during winter-spring, emission processes of ultrafine sea-salt particles remain unclear.

\subsection{Low number fraction of non-volatile particles in the winter}

Figure 9 presents variations of abundance of non-volatile particles, $\mathrm{CN}$ concentration and wind speed during the winter. The $\mathrm{CN}$ concentration increased remarkably under the storm conditions with strong winds. Similar variations were observed in winter-spring at Syowa (e.g. Ito, 1981; Hara et al., 2010) and in summer at Aboa (Virkkula et al., 2007). Simultaneously, higher abundance of non-volatile particles was observed in higher $\mathrm{CN}$ concentration and strong winds, although the abundance dropped to less than $30 \%$ when the wind speed was low and $\mathrm{CN}$ concentration decreased. The five-day backward trajectory was computed to compare features of abundance of non-volatile particles and the air mass history. The trajectory was calculated in vertical motion

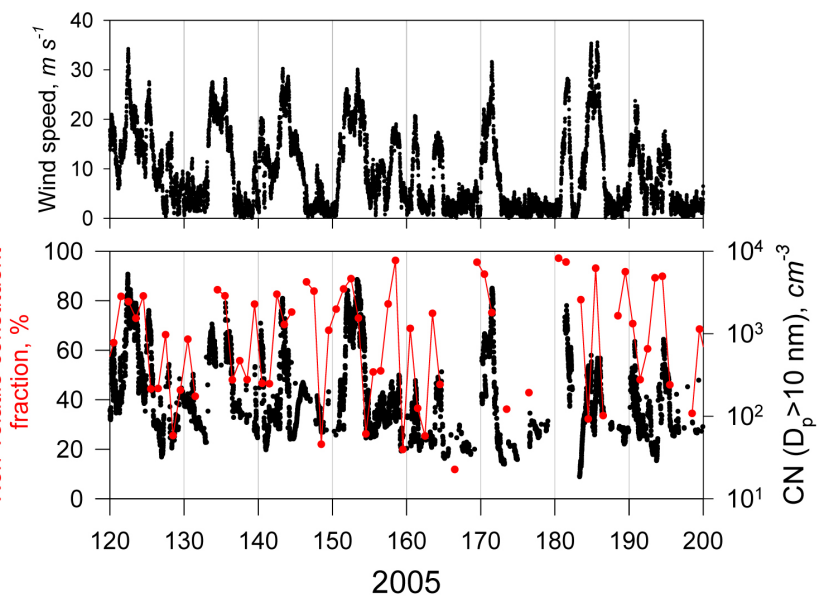

Fig. 9. Variations of hourly mean wind speed, hourly mean $\mathrm{CN}$ concentration, and daily mean number fraction of non-volatile particles at Syowa Station during winter.

mode using the NOAA HYSPLIT model and the NCEP reanalysis dataset (Draxler and Rolph, 2003).

Figure 10 presents examples of the backward trajectory. An air mass with high abundance of non-volatile particles (day of year $=153$ and 171; 3 and 21 June) approached Syowa Station from the Southern Ocean, sea-ice zone and coastal areas. This air mass history was consistent with the high number fraction of ultrafine particles and high concentrations of sea-salts (e.g. $\mathrm{Na}^{+}$and $\mathrm{Cl}^{-}$), as described above. A similar air mass history was obtained in storm conditions and high concentrations of sea-salt particles $\left(\mathrm{Na}^{+}\right)$(Hara et al., 2004). An air mass in low abundance of non-volatile particles (day of year $=130$ and 167; 11 May and 17 June) originated from the free troposphere over the Antarctic continent. Because of the great distance from the ocean and seaice, it is expected that the aerosol number concentrations and the concentration of sea-salt particles were lower in the free troposphere over the Antarctic continent during the winter.

To compare the number fractions of non-volatile particles in each air mass origin during the winter-spring (MaySeptember), the number fraction was divided based on air mass origin. Here, air mass origin was classified into (1) Antarctic continent $\left(>70^{\circ} \mathrm{S}\right)$, (2) Antarctic coast (65$\left.70^{\circ} \mathrm{S}\right)$ and (3) Ocean $\left(<65^{\circ} \mathrm{S}\right)$ using the end-points of 5-day backward trajectory. Figure 11 presents the number fractions of non-volatile particles in each air mass in MaySeptember when the number fractions of non-volatile particles increased. The number fraction in the air mass origin of continent was obviously lower relative to that in Antarctic coast and Ocean. Thus, air mass origin might be related closely to abundance of non-volatile particles during the winter-spring. Indeed, tethered balloon-borne aerosol measurements at Syowa Station have revealed that the CN concentration in the lower free troposphere in June-July was $<50 \mathrm{~cm}^{-3}$ (minimum concentration; ca. $7 \mathrm{~cm}^{-3}$ ) (Hara et 

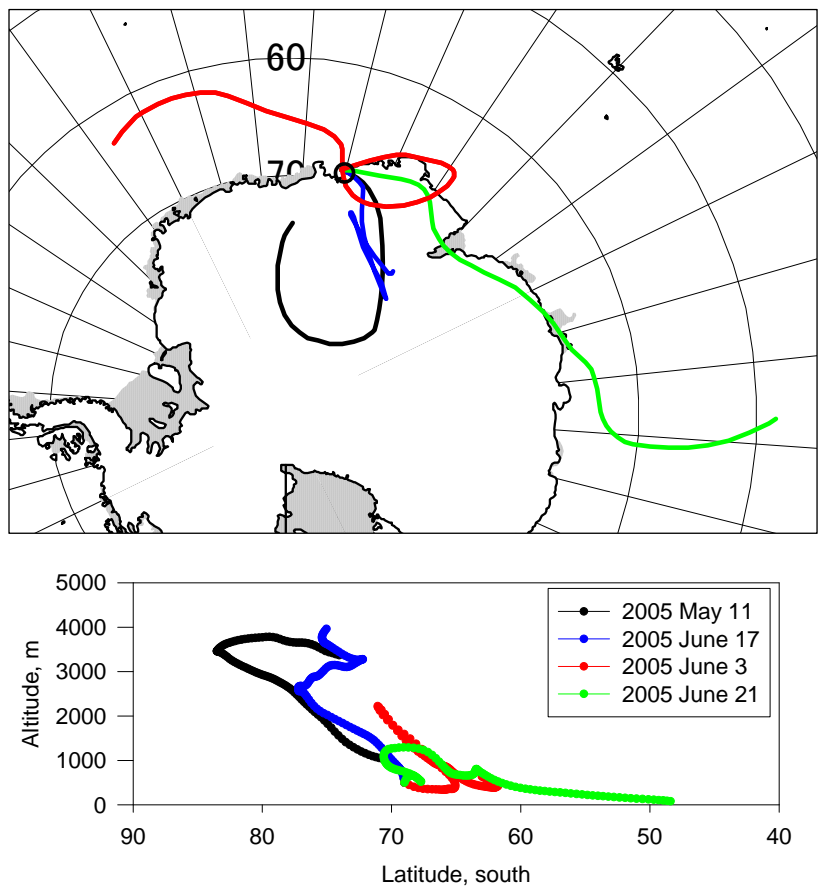

Fig. 10. 5-day backward trajectories in the lower and higher number fraction of non-volatile particles during the winter at Syowa Station. Circles mark the location of Syowa Station.

al., 2011b). In addition, higher relative abundance of sulfate particles in fine mode $\left(D_{\mathrm{p}}: 0.2-2 \mu \mathrm{m}\right)$ was obtained in the boundary layer and lower free troposphere at Syowa Station on 16 June (Hara et al., 2011a). Although sea-salt particles were dominant usually in the winter, the abundance of volatile particles such as sulfate particles can increase in the air mass from the free troposphere over the continent, even in winter.

\subsection{Atmospheric implications of ultrafine sea-salt particles}

As depicted in Fig. 9, CN concentrations can increase to the order of hundreds, even in the winter, during storm conditions (Iwai, 1979; Hayashi et al., 2010; Hara et al., 2010). As described above, ultrafine particles were predominantly composed of sea-salts in the boundary layer in winter-spring. Although ultrafine particles were formed from aerosol precursors derived from oceanic bioactivity during the summer (e.g. Ito, 1993), the supply of sea-salt particles might contribute substantially to the sustenance of ultrafine particles in the Antarctic coasts during winter-spring. Yamanouchi et al. (1999) reported that aerosols were enhanced in both the boundary layer and the free troposphere over the Antarctic coasts after the passing of a cyclone. Because Sea-salts are hygroscopic species, the dominance of sea-salt particles during winter-spring strongly suggests that dispersion of sea-salt particles supplied from sea ice and the sea sur-

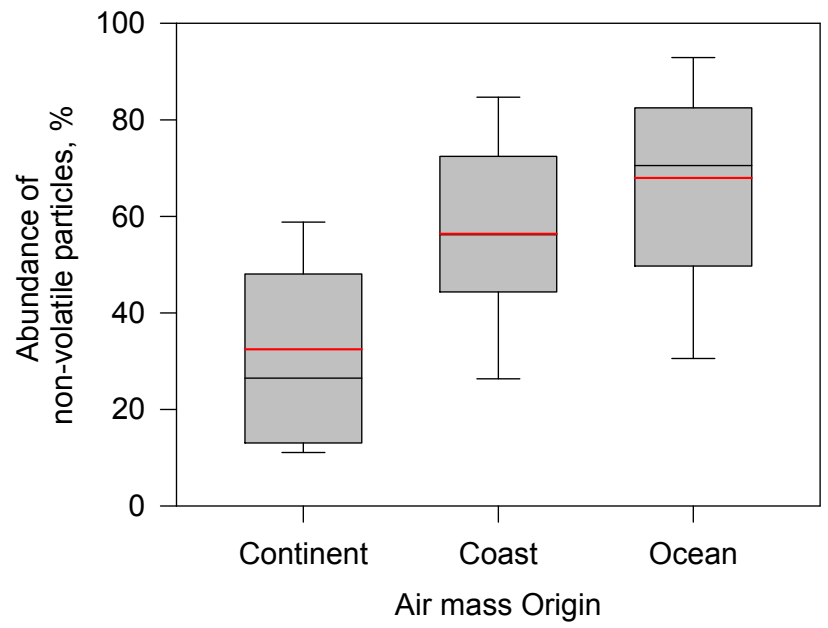

Fig. 11. Number fractions of non-volatile particles in each air mass origin during May-September. The upper bar, upper box line, black middle box line, bottom box line, and bottom bar respectively denote values of $90 \%, 75 \%, 50 \%$ (median), $25 \%$ and $10 \%$. The red line represents mean values.

face might be an important $\mathrm{CCN}$ source in the Antarctic troposphere during winter-spring. The number concentration of sea-salt particles was too low to make a direct effect on climate change. When sea-salt number density is enhanced by strong winds and large sea-ice extent, sea-salt particles are expected to affect the radiation budget and climate during winter-spring in Antarctic regions through cloud formation (i.e. indirect effect). For instance, cloud appearance might have potential to reduce radiative cooling in the winter. To elucidate the contribution of sea-salt particles, additional field observations and model estimation are needed in the future.

\section{Summary and conclusions}

Size distributions and volatility of ultrafine and fine aerosol particles were measured using SMPS and TSMPS at Syowa Station, Antarctica from February 2005 until July 2006. Most particles in fine mode were vaporized when exposed to $100^{\circ} \mathrm{C}$ during the summer and the ultrafine mode shifted to a smaller size in many cases. Furthermore, most ultrafine particles were volatized when exposed to $240^{\circ} \mathrm{C}$. The abundance of volatile particles increased up to more than $90 \%$ during summer. Aerosol constituents in ultrafine particles $\left(D_{\mathrm{p}}<0.2 \mu \mathrm{m}\right)$ were dominantly $\mathrm{SO}_{4}^{2-}$ and $\mathrm{CH}_{3} \mathrm{SO}_{3}^{-}$. Large volatility was found in $<100^{\circ} \mathrm{C}$ and in $150-210^{\circ} \mathrm{C}$. Consequently, major aerosol constituents might be $\mathrm{CH}_{3} \mathrm{SO}_{3} \mathrm{H}-$ $\mathrm{H}_{2} \mathrm{SO}_{4}$ and ammoniated sulfates and methanesulfonates.

In contrast to high volatility in the summer, ultrafine mode was not shifted at exposure of $100^{\circ} \mathrm{C}$ during the winter-spring. Most particles were retained during exposure 
of $240{ }^{\circ} \mathrm{C}$. Abundance of non-volatile particles increased occasionally to more than $90 \%$ in high $\mathrm{CN}$ concentration during the winter-spring, although the abundance dropped occasionally to ca. $20 \%$ at lower $\mathrm{CN}$ concentrations, even in the winter-spring. During the winter-spring, sea-salt particles (e.g. $\mathrm{Na}^{+}$and $\mathrm{Cl}^{-}$) were dominant in all size fractions. Therefore, non-volatile particles were predominantly composed of sea-salts. Furthermore, some sea-salt particles in ultrafine mode might be released from the sea-ice.

Abundance of non-volatile particles decreased to ca. $20 \%$ (similar to abundance in the summer), even in the winter. Higher abundance of non-volatile particles corresponded to air mass transport from the Southern Ocean and coastal areas. Lower abundance was obtained when air masses were transported from the free troposphere over the Antarctic continent. Volatile particles such as sulfates were dominant in the free troposphere, even during the winter, although the $\mathrm{CN}$ concentration decreased to the order of tens per cubic centimeter (occasionally $<10 \mathrm{~cm}^{-3}$ ) in the free troposphere during the winter.

Acknowledgements. We thank the members of the 46th and 47th Japanese Antarctic Research Expedition for assistance with aerosol measurements at Syowa Station. This study was supported by the "Observation project of global atmospheric change in the Antarctic" for JARE 43-47. This work was also supported by a Grant-in Aid (No. 16253001, PI: T. Yamanouchi, and No. 15310012, PI: K. Osada) from the Ministry of Education, Culture, Sports, Science and Technology of Japan. The authors gratefully acknowledge the NOAA Air Resources Laboratory (ARL) for providing the HYSPLIT transport and dispersion model and READY website (http://www.arl.noaa.gov/ready.html) used for this research.

Edited by: V.-M. Kerminen

\section{References}

Asmi, E., Frey, A., Virkkula, A., Ehn, M., Manninen, H. E., Timonen, H., Tolonen-Kivimäki, O., Aurela, M., Hillamo, R., and Kulmala, M.: Hygroscopicity and chemical composition of Antarctic sub-micrometre aerosol particles and observations of new particle formation, Atmos. Chem. Phys., 10, 4253-4271, doi:10.5194/acp-10-4253-2010, 2010.

Bodhaine, B. A.: Aerosol absorption measurements at Barrow, Mauna Loa and the South Pole, J. Geophys. Res., 100, 89678975, 1995.

Charlson, R. J., Lovelock, J. E., Andreae, M. O., and Warren, S. J.: Oceanic phytoplankton, atmospheric sulphur, cloud albedo and climate, Nature, 326, 655, doi:10.1038/326655A0, 1987.

Clarke, A. D., Owens, S. R., and Zhou, J.: An ultrafine sea-salt flux from breaking waves: Implications for cloud condensation nuclei in the remote marine atmosphere, J. Geophys. Res., 111, D06202, doi:10.1029/2005JD006565, 2006.

Draxler, R. R. and Rolph, G. D.: HYSPLIT (HYbrid Single-Particle Lagrangian Integrated Trajectory) Model access via NOAA ARL READY Website (http://www.arl.noaa.gov/ready/hysplit4.html), NOAA Air Resources Laboratory, Silver Spring, MD, 2003.
Gras, J. L.: Condensation nucleus size distribution at Mawson, Antarctica: seasonal cycle, Atmos. Environ., 27, 14171425, 1993.

Hara, K., Osada, K., Kido, M., Hayashi, M., Matsunaga, K., Iwasaka, Y., Yamanouchi, T., Hashida, G., and Fukatsu, T.: Chemistry of sea salt particles and inorganic halogen species in the Antarctic regions: Compositional differences between coastal and inland stations, J. Geophys. Res., 109, D20208, doi:10.1029/2004JD004713, 2004.

Hara, K., Osada, K., Yabuki, M., Hayashi, M., Yamanouchi, T., Shiobara, M., and Wada, M.: Measurement of black carbon at Syowa station, Antarctica: seasonal variation, transport processes and pathways, Atmos. Chem. Phys. Discuss., 8, 98839929, doi:10.5194/acpd-8-9883-2008, 2008.

Hara, K., Osada, K., Yabuki, M., Hashida, G., Yamanouchi, T., Hayashi, M., Shiobara, M., Nishita, C., and Wada, M.: Haze episodes at Syowa Station, coastal Antarctica: Where did they come from?, J. Geophys. Res., 115, D14205, doi:10.1029/2009JD012582, 2010.

Hara, K., Osada, K., and Yamanouchi, T.: Seasonal features and vertical distributions of aerosol constituents in the lower troposphere of the Antarctic coasts, in preparation, 2011a.

Hara, K., Osada, K., Nishita-Hara, C., and Yamanouchi, T.: Seasonal variations and vertical features of aerosol particles in the Antarctic troposphere, Atmos. Chem. Phys., 11, 5471-5484, doi:10.5194/acp-11-5471-2011, 2011 b.

Hayashi, M., Osada, K., Hara, K., Yabuki, M., Kobayashi, H., Ihara, S., Wada, M., Yamanouchi, T., Hashida, G., and Shiobara, M.: Monitoring of aerosol concentration at Syowa Station, Antarctic Records, 54, 474-486, 2010 (in Japanese with English abstract).

Ito, T.: Antarctic Submicron Aerosols and Long-Range Transport of Pollutants, Ambio, 18, 34-41, 1989.

Ito, T.: Size distribution of Antarctic submicron aerosols, Tellus, 45B, 145-159, doi:10.1034/j.1600-0889.1993.t01-1-00007.x, 1993.

Ito T. and Iwai, K.: On the sudden increase in the concentration of Aitken particles in the Antarctic atmosphere, J. Meteorol. Soc. Jpn., 59, 262-271, 1981.

Iwai, K.: Concentration of the Aitken Particles Observed at Syowa Station, Antarctica: A Preliminary Report, Antarctic Records, 67, 172-179, 1979 (in Japanese with English abstract).

Jaenicke, R., Dreiling, V., Lehmann, E., Koutsenoguii, P. K., and Stingl, J.: Condensation nuclei at the German Antarctic Station “Georg von Neumayer", Tellus, 44, 311-317, 1992.

Koponen, I. K., Virkkula, A., Hillamo, R., Kerminen, V.-M., and Kulmala, M.: Number size distributions and concentrations of the continental summer aerosols in Queen Maud Land, Antarctica, J. Geophys. Res., 108, 4587, doi:10.1029/2003JD003614, 2003.

Kusunoki, K.: Variations of sea-ice conditions in Lützow-Holm Bay area, in Antarctica, in the last 20 years, Sea level, ice, and climate change (Proceedings of the Canberra Symposium), IAHS Publ. No. 131, 171-176, 1979.

Mårtensson, E. M., Nilsson, E. D., de Leeuw, G., Cohen, L. H., and Hansson, H.-C.: Laboratory simulations and parameterization of the primary marine aerosol production, J. Geophys. Res., 108, 4297, doi:10.1029/2002JD002263, 2003.

Meskhidze, N. and Nenes, A.: Phytoplankton and Cloudiness in the Southern Ocean, Science, 314, 1419-1423, 2006. 
Minikin, A., Legrand, M., Hall, J., Wagenbach, D., Kleefeld, C., Wolff, E., Pasteur, E., and Ducroz, F.: Sulfur-containing species (sulfate and methanesulfonate) in coastal Antarctic aerosol and precipitation, J. Geophys. Res., 103, 10975-10990, 1998.

O'Dowd, C. D. and Smith, M. H.: Physicochemical Properties of Aerosols Over the Northeast Atlantic: Evidence for Wind-SpeedRelated Submicron Sea-Salt Aerosol Production, J. Geophys. Res., 98, 1137-1149, 1993.

O'Dowd, C. D., Lowe, J. A., Smith, M. H., Davison, B., Hewitt, C. N., and Harrison, R. M.: Biogenic sulphur emissions and inferred non-sea-salt-sulphate cloud condensation nuclei in and around Antarctica, J. Geophys. Res., 102, 12839-12854, 1997.

Osada, K., Hara, K., Wada, M., Yamanouchi, T., and Matsunaga, K.: Lower tropospheric vertical distribution of aerosol particles over Syowa Station, Antarctica from spring to summer 2004, Polar Meteorol. Glaciol., 20, 16-27, 2006.

Osada, K., Nishita-Hara, C., Hara, K., Yabuki, M., Shiobara, M., Wada, M., Yamanouchi, T., and Hayashi, M.: Seasonal variation of size distribution of submicrometer aerosol particles at Syowa Station, Antarctica, Antarctic Records, 54, 530-540, 2010 (in Japanese with English abstract).

Park, J., Sakurai, H., Vollmers, K., and McMurry, P. H.: Aerosol size distributions measured at the South Pole during ISCAT, Atmos. Environ., 38, 5493-5500, 2004.
Shaw, G. E.: Bio-controlled thermostasis involving the sulfur cycle, Climatic Change, 5, 297-303, 1983.

Shaw, G. E.: Antarctic Aerosols: A Review, Rev. Geophys., 26, 89-112, 1988.

Virkkula, A., Hirsikko, A., Vana, M., Aalto, P. P., Hillamo, R., and Kulmala, M.: Charged particle size distributions and analysis of particle formation events at the Finnish Antarctic research station Aboa, Boreal Environ. Res., 12, 397-408, 2007.

Wagenbach, D., Ducroz, F., Mulvaney, R., Keck, L., Minikin, A., Legrand, M., Hall, J. S., and Wolff E. W.: Sea-salt aerosol in coastal Antarctic regions, J. Geophys. Res., 103, 10961-10974, 1998.

Weller, R., Jones, A. E., Wille, A., Jacobi, H.-W., McIntyre, H. P., Sturges, W. T., Huke, M., and Wagenbach, D.: Seasonality of reactive nitrogen oxides (NOy) at Neumayer Station, Antarctica, J. Geophys. Res., 107, 4673, doi:10.1029/2002JD002495, 2002.

Wilson, T. R.: Salinity and the major elements of sea-water, in: Chemical Oceanography, edited by: Riley, J. P. and Skirrow, G., Academic Press. Inc., San Diego, California, 365-413, 1975.

Yamanouchi, T., Wada, M., Fukatsu, T., Hayashi, M., Osada, K., Nagatani, M., Nakata, A., and Iwasaka, Y.: Airborne observation of water vapor and aerosols along Mizuho Route, Antarctica, Polar Meteorol. Glaciol., 13, 22-37, 1999. 